\title{
Organic global cryptocurrency: towards a stable international monetary system that is closer to Maqāșid Sharīiah
}

\author{
Abdurrahman Arum Rahman \\ Global Currency Initiative, Jakarta, Indonesia
}

\begin{abstract}
Purpose - The most prominent and persistent problems of our global monetary system are instability and imbalances. We propose an international monetary model to solve these problems while at the same time move the model closer to Maqāșid Sharía ah (objectives of Sharīa ah). We name this an organic global monetary model or abbreviated as OGM. OGM is an international monetary model directly built on the national monetary system of each member country so that the two can co-exist.

Design/methodology/approach - Model design, theory and literature.

Findings - The model can eliminate interest rates at the central bank level, create non-tradable international money, and make a more stable international monetary system.
\end{abstract}

Originality/value - Original.

Keywords Global currency, Zero interest rate, Non-tradable money

Paper type Conceptual paper

\section{Introduction}

\subsection{Problem of instability}

The most prominent and persistent problems of the global monetary system are instability and imbalances. Since the collapse of the Bretton Woods, financial markets have grown faster than any other market in the world. In 1996, Kruger $(1996$, p. 17) found that currency transactions were 40-50 times bigger than global trade. That means a very large part of currency transactions were without real economic activity or, as often called, "noise transaction."

Based on his research, Hayward (2018) stated that noise transactions and excessive speculation lead to overshooting and increased risk. Money trade sucks up huge amounts of capital, while on the other hand, it does not add value to output. Instead, it increases fluctuations and uncertainties. Various countries around the world have experienced such speculative attacks, including European countries (Eichengreen et al., 1994), Southeast Asia (Zhang, 2001), Latin America (Reisen, 1998) and so on. Countries in the world have to build strong and expensive forex reserves to face the threat. They sometimes raise interest rates to slow down the economy to do so. All of those efforts are very expensive both monetary and economically.

\section{JEL Classification - E40, E50, F40. KAUJIE Classification - Q0, U0}

(C) Abdurrahman Arum Rahman. Published in Islamic Economic Studies. Published by Emerald Publishing Limited. This article is published under the Creative Commons Attribution (CC BY 4.0) license. Anyone may reproduce, distribute, translate and create derivative works of this article (for both commercial and non-commercial purposes), subject to full attribution to the original publication and authors. The full terms of this license may be seen at http://creativecommons.org/licences/by/4.0/ legalcode

I express my deepest gratitude to the editors of the journal. I also express my deepest thanks to the anonymous reviewers who provided valuable input.

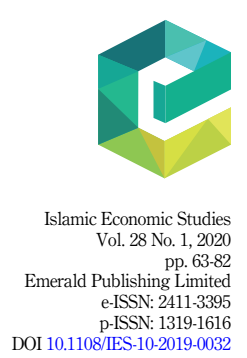


IES

28,1

64

The floating exchange rate that is used by almost all countries in the world today causes fluctuations. Fluctuations open up speculation opportunities. Various banking and financial institutions also issue derivatives that ultimately enlarge the speculation market. The money market is growing bigger than any other market on earth, turning over 6.6 trillion dollars each day (BIS, 2019). There is no other market on earth of this size. Most of this huge transaction is speculative. Real transactions are like surfing on a "giant tide" of noise transactions. It is impossible to make international monetary stable this way.

The imbalance is not much different. Global imbalances always grow consistently and globally, causing crises in many countries and only shrinking when crises occur (Obstfeld and Rogoff, 2010). The imbalance is an inherent part of our international monetary system for decades.

Various international monetary reform ideas emerged to solve the problem. The most radical and comprehensive is the "Keynes Plan" or "Bancor", which was propagated by the most prominent modern economist, John Maynard Keynes. Bancor is supposed to be a symmetrical and democratic monetary system in which all countries have equal access to international currencies and all countries have proportional quotas. The value of the currency is stable because it is pegged to gold. Exchange rates between currencies are also stable because all currencies are pegged to a fixed value. The external balance should be maintained because countries that experience surpluses or deficits more than a certain limit get disincentives (Keynes, 1969). It's just that, as we know, Keynes's plan was not approved.

After Keynes, dozens of other proposals emerged. To reduce the adverse effects of rapid capital flows and transactions between currencies, Tobin (1978) proposed a tax on currency transactions which became well-known as "Tobin Tax". Mundell (2003) proposed the merge of the dollar, euro and yen into a single powerful reserve currency, DEY. The three economies, at the time (before the emergence of China as a global power), controlled almost $50 \%$ of the global economy. By combining the largest currencies in the world, frictions will be significantly reduced and the international monetary system will be more stable. Another merging idea was proposed by Cooper (2006) by combining the currencies of all OECD countries. Moore (2004) proposed the adoption of the US dollar and the euro by all countries in the world to become international currencies and at the same time national currencies so that there are only two currencies in the world. He called the idea "Dollarization and Euroization". Bonpasse (2006) proposed a "radical" single global currency that replaces all currencies in the world. He called the idea a single global currency with $3 \mathrm{G}$ (global central bank, global currency and global union). Greenwald and Stiglitz (2009) proposed the formation of a global reserve fund (GRF) which is jointly managed by countries that join the "club". Each member country contributes capital to the GRF and in return, they get a "global greenback" (reserve currency). In a moderate form, the global greenback is only held by the central bank, while in a radical form it is held by the public or becomes an actual hard currency. Exchange rates may use the current system. The most widely discussed proposal is the extension or empowerment of the SDR that was proposed by many experts inside and outside the IMF (IMF, 2010) and (IMF, 2011). This is since SDR has been effectively used as a supplement of global reserves for decades and was issued by a very credible international institution, the IMF.

\subsection{Closer to Shari ah principle}

Choudhury (2018) defined the money in Islam as micro-money. Micro-money is simply defined as money that is only used in real economic activity. The function of money that is not related to real activities such as currency trading, derivative transactions, even the interest rate, is not included in the micro-money. The definition of micro-money by Choudhury is still at the conceptual phase and may continue to develop more definitively.

We propose a shared-international monetary model that can be built on a regional or global scale that is closer to the definition of "micro-money" or money that only carries out a real 
economic activity. We call it organic global monetary model (OGM) or simply call it an organic model. The organic model is built and managed by all member countries in the world so that it becomes both democratic and symmetrical. The model aims to eliminate instabilities, imbalances, inefficiencies and incoherencies in the current international monetary system. In doing so, the organic model follows basic theories in the open economy. Assessed from this direction, the organic model is on its way to achieve the Maqūssid Sharíah.

First, the organic model makes global monetary system more symmetrical; that is managed jointly by all countries in the world and is organically connected with the national currencies of all member countries. Therefore, the organic model is more symmetrical and more democratic than the current model. Thus global imbalances can be eliminated and global inequality can be reduced significantly. We believe that eliminating imbalances, inequality, and injustice is part of the Maqāșid Shariah.

Second, the organic model can be controlled directly so that it does not require the interest rate at the central bank or government level. We believe that in the absence of the interest rate at the central bank level, eliminating the interest rate at the lower level will be more likely than in the current model. Without the interest rate, the cost of monetary control becomes more efficient.

Third, the model uses an exchange rate system that can eliminate both volatilities and spreads while on another hand still maintain flexibility. With the loss of volatility and spreads, the organic model removes currency speculation from the very basics: the opportunity. This is a very deep achievement in the Maqūṣid Sharíah.

\subsection{Development}

For implementation, this new model requires technologies that currently exist, namely cryptographic technology and is decentralized. Further development of models, systems and technology is needed and can be done openly.

By using a fully flexible exchange rate as will be explained later, the organic model does not require economic integration, so it can start anywhere in the world and any country may join. The organic model can start on a small scale or regional such as ASEAN, East Asian, Middle East, South Asian, East Africa, West Africa, Latin America and many others. It can also start from interconnected regions or multi-regions. It can also start on a global scale. Wherever the organic model begins, it can be opened to all countries in the world; all countries may join; no need for economic integration.

The stages of development from the initiative to the implementation are as follows:

(1) Initiative, further research and development

Since the organic model is "infant", further developments and initiatives are still needed. The purpose of the initiative is conducting further research and development of models, theories and technology; inviting all parties, both individuals and institutions and so on to take apart. Under the principle of decentralization used in the organic model, the initiative is also carried out with the same principle, decentralized. Everybody in all corners of the world is free to take part. Relationships between initiatives are cooperative and mutually coordined.

\section{(2) Governments to take control}

At present, money is only valid if issued by the agency that has the greatest authority in the world, namely, the government. Therefore, at some point, the initiative must be able to invite each government to take over. Furthermore, the initiatives continue under the coordination of the government of each country. The final goal of the next initiative is for the governments of these countries to establish an "official inter-governmental body" to materialize a joint international monetary system. The body should ideally coordinate with the UN and/or the IMF. The main task of the body is to prepare all the necessary regulations, establish the global central bank, outline and control its journey. 
IES

28,1

66

To be effective, countries that join the "official inter-governmental body" are only countries that want to join, while those that are not interested can stay out. Since the organic model is fully open; it is free for all countries to join or not.

(3) To establish a global central bank

The last milestone of the initiative is to establish a global central bank. The global central bank is the official body that issues organic international cryptocurrency and regulates its circulation in all member countries. The global central bank is responsible to the official intergovernmental body. The global central bank has branches in each country that work closely with the national central bank to regulate the circulation of organic cryptocurrency and exchange rate with national currencies.

\subsection{Provide choices}

This research aims to provide an alternative for a stable-and-symmetrical international monetary system that operates all international monetary functions while maintaining the external balance of each country in all conditions. The organic model distributes an international cryptocurrency to all member countries freely; there is no need for any country to buy currencies from others. The model provides an international monetary system that is independent of the state budget and national interest of certain countries. The model provides an international monetary system that is very different from today's system, where it is more stable, efficient and symmetrical; it opens up the opportunity to increase economic growth and global welfare in the new boundary. And it is closer to the Maqașid Sharíah.

\section{The model}

Organic global monetary model (OGM) is an international monetary system that is democratically developed by all member countries in the world directly on the national monetary system of each member country and becomes part of them (Rahman, 2020, Section 6.1). Since OGM uses cryptographic technology, we can call the currency as "organic global cryptocurrency" or OGC.

OGC is only used for international transactions between member countries. Domestic transactions still use the national currency of each country. The relationship between the OGC and the national currency is organic (part of) and hybrid (interchangeable). The organic currency is controlled by a global central bank that is jointly managed, while national currency remains controlled by each country. This makes member countries not to lose sovereignty. They still use the national currency and fully control the national monetary system.

The organic model uses an auto-balancing exchange rate system that follows the economic fundamentals of each member country so that it does not cause fluctuations on one side and also does not cause an asymmetric shock and external imbalances on the other side. By following each country's fundamentals, organic monetary model does not require economic integration or OCA properties as required in the single currency model such as euro. So the OGM can be applied to all countries in the world in their current conditions and without overhauling national monetary systems.

\subsection{Organic}

The relationship between the OGC and the national currency is organic (part or organ). OGC does not stand alone but becomes part (organ) of the national currency of each member country and is an extension of it. Countries that join the organic model extend their national currencies as much as they need for international transactions between them. This extended national currency is then replaced by the OGC. The extended national currency which is 
replaced is kept as collateral, whereas the OGC is used as international currency between members (see Figure 1).

As a guarantee, national central banks of member countries give back their respective national currencies to the global central bank. The global central bank holds those national currencies as collateral. The total value of the OGC given to member countries and national currencies used as collateral is always the same. When the national currency depreciates against the OGC, the member country sends the shortfall to the global central bank so that the value is the same again. And vice versa. As a result, the value of the OGC circulating through member countries is always the same as the guarantees (national currencies) that they deposited. The guaranteed value and OGC that is always the same is called a "one floating value" (Rahman, 2020, Section 6.8).

The amount of OGC circulating in all member countries is determined by the global central bank following the needs of international trade, investment and other transfers among member countries. This number is called the "ideal number".

\subsection{Open membership and closed system}

Membership in the organic model is fully open. All countries may join without the need for economic integration. Since the organic model uses an exchange rate that is fully flexible following economic fundamentals (which will be explained later), it does not require economic integration.

The organic model uses a closed system. OGC only circulates among member countries and cannot be used for transactions outside members.

\subsection{Distribution to the public and control system}

OGC distribution from the national central bank to the public is done directly. To issue, the national central bank sells OGC to the public using the national currency. Revenue (seigniorage) becomes government revenue. Conversely, to withdraw, the national central bank buys OGC from the public using the national currency. Withdrawal costs (purchases) become an expense (negative seigniorage) for the government.

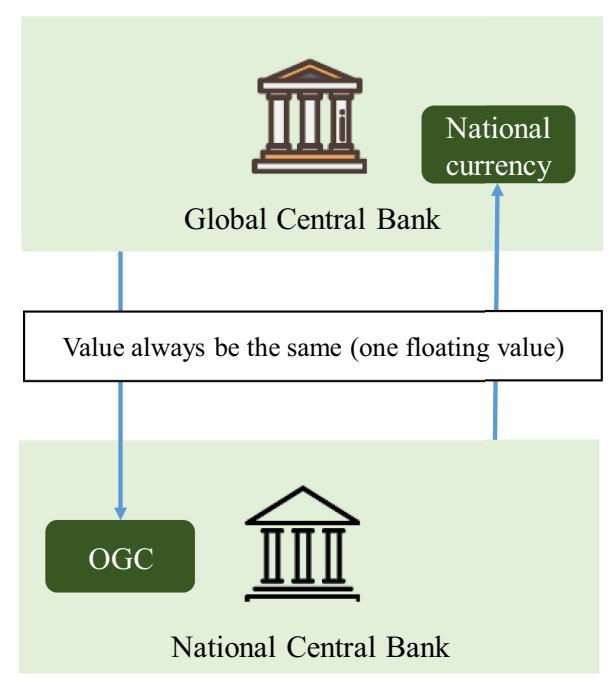

Figure 1. OGC distribution model to member countries 
IES

28,1

68

When the amount of OGC in circulation is below or equal to the "ideal number", the central bank exercises "passive control". This means that the central bank only accepts "purchases and sales" from the public. No intervention needed.

When the amount of OGC in circulation exceeds the ideal amount, i.e. when the people of that country use the organic currency for domestic transactions or to store domestic assets, the local government exercises "active control". Active control can be in the form of recommendations for the use of national currencies; it can also be in a more progressive fashion such as the "tax of holding organic cryptocurrency".

As mentioned earlier, OGC is only intended for international transactions, not for domestic transactions and not to replace the national currency. However, such direct prohibitions are difficult to implement. Therefore, the solution is through disincentives. And the disincentive is done by the local government. Excessive use of OGC for domestic transactions is detrimental to the country itself because it will reduce the use of national currencies, while excessive use of OGC to import or for international transfers is not possible because the autobalancing exchange rate system always balances the external balance, as will be explained later.

This (circulation) control system is called the "direct control". Thus, the organic model does not require interest rates (zero-interest rate) to control monetary flow. Instead, it uses direct control, as the picture below describes (Rahman, 2020, Section 6.6) (see Figure 2).

\subsection{Digitization and decentralization}

To get more accurate calculations and controls of money circulation (speed and volume), the organic model uses digital cryptocurrency or cryptographic technology and is decentralized. Digital systems can make transactions between countries as fast as light, literally. The most popular current international transactions between countries, wire transactions, take between 3-5 business days at a significant cost. The transactions require a lot of human interventions and reconciliations. All these cost resources and time, while digital transactions can be done in just minutes or seconds. Many human touches can be skipped. Digitation can accelerate global transactions thousands of times at a much lower cost.

Cryptocurrency is a digital currency or assets created to be a medium of exchange or digital assets, using cryptographic technology (Chohan, 2017). Cryptography itself is the use of mathematical techniques to secure digital information, systems and networks from attack or hacking (Katz and Lindell, 2015). Simply put, the cryptographic technique allows the creation of digital currency units in which each unit has a serial number and only circulates in the main network and is well protected. The implementation of cryptographic technology in the organic model is different from current cryptocurrencies, such as bitcoin, because bitcoin is made not to be controlled, whereas the OGC, with the same technology, is made to be fully

Figure 2.

OGC in circulation and direct control
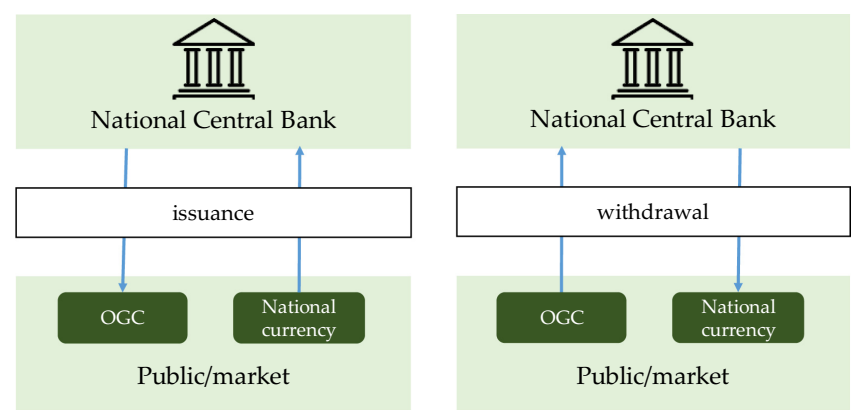
controlled by governments. In digital form, OGC circulation can be fully controlled and fully recorded accurately. No single unit can leave the network or be unrecorded.

In the cryptocurrency world, decentralization, or better known as a decentralized organization (DA) or a decentralized autonomous organization (DOA) is "an organization that, under predefined rules, operates autonomously or semi-autonomously in an open-source software which is distributed across all (computers) stakeholders, transparent, secure and auditable" (Aste et al., 2017). While according to Hsieh et al. (2018), DAO is an "organization that uses software rules to execute organizational routines, plus votes from some class of members to alter and extend those routines. No direct management is required".

Decentralization in the organic model is slightly different from what is in the cryptocurrency world. In the organic model, the member class that becomes a core, has voting rights and makes regulations is the government, whereas the public only receives services. So decentralization in the organic model is only up to the government level of each country that runs a decentralized system.

Simply put, decentralization is a system that is run by all members (governments) based on consensus without a center and thus does not have a dependency on a particular center or member. When a failure occurs in some systems or even most systems, other systems that are still working can run normally. Each member country is a "core" that runs at least one supercomputer in each country. All of these supercomputers are connected to a "backbone" network which is also managed together in a decentralized way. System failure in one country or several countries (cores) will not cause failure in other countries (cores) (see Figure 3)

At present, many stable cryptocurrency systems that are backed up with liquid valuable assets such as dollars, precious metals, commodities or other assets, which use cryptographic technology, both centralized and semi-decentralized are operational. According to Clark (2020), as of early 2020, 41 crypto-platforms that were backed up with gold are operational. Another cryptocurrency model that is backed up with commodities is Terra or Trade Reference Currency (TRC) developed by Lietaer (2017) or metal-backed cryptocurrency proposed by Ajouz et al. (2019).

The development of cryptographic technology for the organic currency that is interchangeable with national currencies can also be done using the same method. The development may be more complicated because it is embedded with an exchange rate system that uses national price indices and global in real-time. The technology will process very large amounts of data throughout the world or member countries in real-time, transparently, and in a decentralized manner.

\subsection{Value}

Since the organic cryptocurrency is not attached to the state budget of any particular country, its value can be made very stable, far more stable than all currencies that have ever existed in

\section{Organic global monetary}

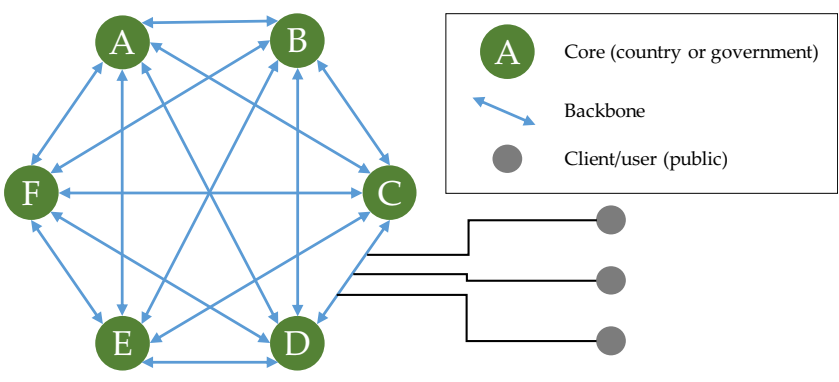

Figure 3. OGM decentralized system: governments as cores and public as users 
IES

28,1 the world, namely "zero depreciation" and "zero appreciation". To achieve such a perfect level of stability, the OGC is pegged to the average prices for goods and services worldwide or more easily called a global price index. Thus, the value of OGC never depreciates nor appreciates. The value this year, next year, 10 years to come, even 100 years to come will remain the same.

To maintain the desired zero-depreciated value, OGC's supply is based solely on the need for the money, i.e. for international transactions. The amount of OGC needs in each country is determined by the global central bank by calculating the international trade and transfers between fellow member countries.

\subsection{Exchange rate}

The exchange rate is the most critical part of the organic model. There are two exchange rate systems in the world today, namely fixed and floating exchange rates. Each has advantages and disadvantages. The fixed exchange rate has high stability but is not flexible, while the floating has high flexibility but is not stable (fluctuating). Most countries in the world use a combination of the two, namely, corrected fixed exchange rates or floating exchange rates with interventions; Krugman and Obstfeld (2003, p. 482) call it the "hybrid" model, not pure fixed, nor floating.

The organic model does not use the two exchange rates above or a hybrid of the two but uses its own called "auto-balancing". The auto-balancing exchange rate is, in principle, the advancement of a real exchange rate that is enhanced with an automatic external balancing factor. Simply put, the auto-balancing aims to create a "true exchange rate" and always maintains "external balance equilibrium" in all conditions. There are two variables in the auto-balancing model, namely the "price variable" and the "external-balance variable".

2.6.1 First, variable: price. As the name implies, the auto-balancing model aims to create an automatic counterweight in global trade. The ideal exchange rate is when the trade power of each country, when connected to global markets, is in a "balanced state". Trade between countries will be balanced if the average prices of all tradable goods and services in those countries are equal. With the balance of trade power of each country, a global balance can be formed. So the similarity of average prices is a powerful tool to balance the trade and finally global balance. The exchange rate in the auto-balancing model is set when the national tradable-price-index is the same as the global tradable-price-index. The equation is as follows (Rahman, 2020, p. Section 7.4):

$$
M_{\text {Global }}=E \cdot M_{\text {Local }} \text { if } \mathrm{PI}_{\text {Local }}=\mathrm{PI}_{\text {Global }}
$$

$E$ : Exchange rate

$M_{\text {Global: }}$ Global currency value (OGC)

$M_{\text {Local }}$ : National currency value

$\mathrm{PI}_{\text {Global: }}$ Global price index

$\mathrm{PI}_{\text {Local }}$ : Local price index

The first variable makes each country's trade power balanced; exports and imports are balanced. When the efficiency of the production system in a particular country increases, the national price index will decrease against the global. The country can produce goods cheaper than others. At that time, the country will export more than it imports. Its trade becomes unbalanced. The auto-balancing model then responds by raising the value of the national currency so that the national price index rises and gets back to being equal to the global price index. Thus, the country's trade returns to a balanced state. The same thing happens when the country experiences an increase in production costs. The organic model responds by lowering the value of the national currency so that its competitiveness remains balanced. 
Simply put, the first variable makes international trade in all countries to be balanced, in all conditions, not surplus and not a deficit.

2.6.2 Second, variable: external balance. The true external balance in all countries is neutral, which is, not a deficit and not a surplus. The parameter is "neutral external balance". If a particular country has a surplus cumulative trade balance, for example, the auto-balancing exchange rate reduces the national currency exchange rate from its original state on a certain scale. And vice versa, if the country has a deficit cumulative balance sheet, the auto-balancing will reduce the national currency exchange rate. Thus the country's external balance tends to return to the "neutral state" or not a deficit and not a surplus. In this case, the scale we use is GDP. The second variable equation is as follows (Rahman, 2020, Section 7.6):

$$
\mathrm{EBV}=\frac{\mathrm{GDP}+\text { Deficit }(\text { trade }+ \text { investment }+ \text { transfers })}{\mathrm{GDP}+\text { Surplus }(\text { trade }+ \text { investment }+ \text { transfers })}
$$

Simply put, the second variable makes external balances of all countries tend to the "neutral state" or not a deficit and not a surplus.

If the two variables above are combined it will become an auto-balancing equation, i.e.:

$$
\text { Autobalancing }=\text { Price var } x \text { External balance var }
$$

or

$$
M_{\text {Global }}=\left(E \cdot M_{\text {Local }} \text { if } \mathrm{PI}_{\text {Local }}=\mathrm{PI}_{\text {Global }}\right) \cdot\left(\frac{\mathrm{GDP}+\text { Deficit }(\text { trade }+ \text { inv }+ \text { trans })}{\mathrm{GDP}+\operatorname{Surplus}(\operatorname{trade}+\operatorname{inv}+\operatorname{trans})}\right)
$$

Theoretically, the auto-balancing exchange rate will make the competitiveness of all countries in the world balanced. Thus, the country's international trade will also be balanced. No matter how big or how small a country's trade, its international trade competitiveness will always be the same. It does not matter how efficient a country's production system is or how bad it is: its international trade competitiveness will always be the same.

The auto-balancing exchange rate also puts the external balance of each member country in the "true equilibrium state". Countries that have a surplus cumulative external balance, their currencies' value will be reduced so that it reverses the balance. And vice versa. Thus, each country's external balance sheet will tend to be "neutral". A neutral external balance is a true equilibrium.

The exchange rate system is integrated with digital systems and works automatically like "smart contracts" in the current cryptography. All member country policies that affect trade between countries such as barriers (import barriers) or dumping (export subsidies) are automatically neutralized by the system. Thus, the trade balance is always in a balanced state, in all conditions.

By pegging the exchange rate to the price index and external balance to the true equilibrium, the auto-balancing makes the exchange rate follow the actual economic fundamentals, as idealized by Mundell (1961), more than the current floating exchange rate. The current floating exchange rate is flexible by following the money market, while money markets are influenced by many factors that cause a gap between the exchange rate and fundamentals or make the exchange rate not follow actual fundamentals. While in the autobalancing model, by making the price index and true equilibrium as a parameter, the exchange rate follows the actual economic fundamentals, the organic model is fully flexible, by following the actual economic fundamentals. Thus, the organic model does not require 
IES

28,1

economic integration or OCA properties. The external balance between countries is always well maintained in a true external equilibrium in all conditions.

\section{Towards global stability}

One of the main objectives of the organic model is to push global stability up to the maximum level, the stability of the international currency itself, the exchange rate, and the whole system.

\subsection{Zero depreciation and zero appreciation}

Since 1913, the US dollar has been depreciating by more than $95.5 \%$. Today's value is only $4.5 \%$ of its value in 1913 (Fred ST Louis, 2020). The euro, since it was first released in 1999, has been depreciating $29 \%$ of its initial value (Inflationtool, 2020). All currencies in the world have been depreciating, both international (major currencies or key currencies) and national currencies. The stronger the currency, the smaller the depreciation, and the weaker the greater.

At least, two things cause all currencies in the world to depreciate:

First, all currencies are attached to the budget of the state issuing them. Currently, all countries utilize expansionary monetary policy (deficit) to increase growth. The deficit is then closed with debt and printing money. As a result, their currencies depreciate (Meltzer, 2004).

Second, countries in the world also use currencies for competitiveness purposes. To increase the competitiveness of international trade, countries in the world maintain the value of their currencies stay low against major currencies so that their export power remains strong. This strategy triggers other countries to do so to prevent competitiveness loss. According to Rodrik (2008), undervaluation of the currency stimulates economic growth. The undervaluation strategy is especially effective for developing countries. Since the United States maintains US dollar depreciation in the range of $2 \%$ per year (Brown, 2016), then all countries in the world are also trying to depreciate their currencies equal to or below the dollar so that their competitiveness is maintained. In the end, all currencies depreciate.

While the OGC is not related to the state budget of any country nor the competitiveness, therefore, the OGC can be designed to be perfectly stable, not depreciate nor appreciate at all.

The following is the OGC value equation (Rahman, 2020, Section 6.8):

$$
M_{v}=K . \mathrm{PI} \text { if } \mathrm{PI}_{n-1}-\mathrm{PI}_{n}=0 \text { or } \Delta \mathrm{PI}=0
$$

$M_{v}$ : OGC value

$K$ : Constants (determined when the first value of OGC is set)

PI: price index

$\mathrm{PI}_{n-1}$ : price index of the previous year

$\mathrm{PI}_{n}$ : current year's price index

$\Delta \mathrm{PI}$ : changes in price index

When illustrated with a graph, the shape is as below: (see Figure 4).

As seen in the bell curve above, the value of the OGC (the blue line) is equal to the peak (mean) curve of the global price index. If the price index goes down, the OGC value will go down. And vice versa. If the price index rises, the OGC value also follows. This means that the OGC value always follows the global price index.

How could the OGC value follow the price index chart above?

First, the global central bank makes a benchmark of OGC value that follows the price index. Then second, the exchange rate system determines the OGC price against the real value of the national currency based on the "auto-balancing exchange rate". In these two ways, the OGC currency value effectively follows the benchmark value. 


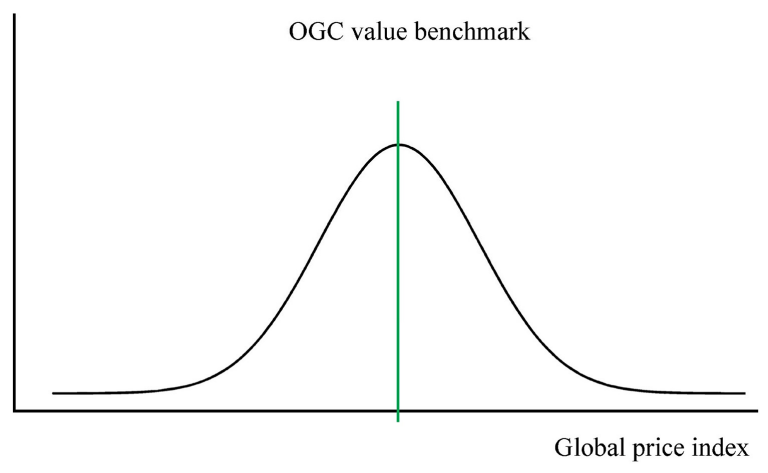

Organic global monetary

Figure 4. OGC value benchmark

Based on QTM (quantity theory of money) theory, the value of money follows the economic value in which the money is used. The simplest money value equation was introduced by Fisher (1911). The equation is:

$$
M . V(\text { money value })=P . T(\text { economic value })
$$

Since OGC is only used for international transactions, P.T is replaced by an international transaction. The equation becomes:

$$
M . V(\text { money value })=P . T(\text { international transactions value })
$$

As mentioned above, the organic model utilizes digital currency technology. With such digital technology, all money in circulation is recorded and controlled. No single unit is unrecorded. Accordingly, then variable $V$ (speed of money), $P$ (price of goods/services in international transactions) and $T$ (number of international transactions) all can be calculated precisely. Thus, $V$ (value and money supply) can be determined precisely. Thus, the value of the OGC, which is zero depreciated and zero appreciated, as desired, can be achieved precisely.

This way, the value of the OGC will always follow the global price index in all conditions precisely. Thus, the value of the OGC will be very stable both in the short term and long, far more stable than all currencies that have ever existed in the world, even gold.

The condition, where the international currency is zero depreciated while national currencies are free to depreciate depending on the preferences and conditions of each country, is something new in global monetary affairs. This has never happened before. It is still the subject of further research on how it impacts on global economic stability and growth.

\subsection{Zero-interest rate}

In the current model, interest rates at the central bank are part of the money itself. All central banks in the world use interest rates as one of the instruments to regulate money. In Shariah commercial banking, the interest rate is replaced with profit-sharing (Rahman, 2007, p. 123). For central banks or government, there are sukuk as a substitute for conventional debt securities. Sukuk are securities with variable-return Sukuk (VRS) and fixed-return Sukuk (FRS) accompanied by underlying real assets or pools of mixed assets (Ayub, 2007, pp. 389-390) and (Siddiqi, 2006, pp. 11-15). According to Afshar (2013), conventional sukuk and debt securities are different because sukuk use collateral of real assets, while conventional uses money (debt). However, according to Wilson (2008, p. 2), sukuk are still widely criticized because they are usually benchmarked to the London Inter-bank Offer Rate (LIBOR) on US dollar funds which are interest rates. 
IES

28,1

Simply put, it is very difficult to eliminate interest or yields at the level of the central bank or government in the current model, some of which are caused by several things below:

(1) To control the circulation of money

The central bank uses interest rates to control money circulation. To reduce the money supply and create a contraction effect, the central bank raises interest rates. Conversely, to reduce the money supply and create an expansionary effect, the central bank reduces interest rates. According to Litterman (1982), using the theory of optimal control of money, a central bank can make an optimal combination of interest rate and money supply so that it can reduce both fluctuations and ultimately maximize employment.

Since the OGC control system is a direct way, interest rates are not needed. OGC circulation is entirely left to the market. If they need it for international transactions they will buy it from the central bank. When they do not need it they just sell it to the central bank. The reason the public use OGC for international transactions is efficiency and convenience: no exchange fees and transfer cost apply. This reason is more than enough for the use of OGC. No additional stimulus is needed. So OGC circulation is very efficient.

Active control is only needed when the public overuse organic currency. Under such conditions, the local government can impose a "tax of holding organic currency". The tax revenue becomes a public fund (government revenue). The interest rate is still not needed.

(2) To control prices (inflation)

Based on the theory of the international Fisher effect (IFE), also known as the Fisher hypothesis (Fisher, 1930), interest rates affect inflation. The higher the interest rate, the higher the inflation, so that real interest rates tend to be constant. Furthermore, in the long run, the relationship between interest rates and inflation is one in one (Westerlund, 2008, p. 195). Various researches were carried out by many parties to test the consistency of Fisher's hypothesis. Most of the last tests were carried out using more complete methods, and in the long run, the consistency was fairly high. Among these tests are Carneiro et al. (2002); Mignon and Lardic (2003); Muse and Alimi (2012), and others.

Simply put, interest rates affect prices and inflation. Therefore, many central banks and governments in the world use interest rates as a tool to control inflation or to achieve a certain level of inflation.

As explained earlier, the organic model fixes the value of the OGC with the global price index so that it is zero depreciation and zero inflation. Thus, the organic model does not require interest rates to control prices (inflation). Inflation is already zero.

(3) To control exchange rates

"The foreign exchange market is in equilibrium when deposits of all currencies offer the same expected rate of return" (Krugman and Obstfeld, 2003, p. 341). The interest rate market tends to equilibrium; that is, the real interest rate throughout the world tends to be the same (interest parity). The reason is, any difference in the real interest rate will cause capital flows between countries, resulting in an adjustment. In this way, the interest rate and the exchange rate affect each other. In this way, governments and central banks use the interest rate to influence the exchange rate, directly or indirectly.

During the Asian monetary crisis in 1997-1998, all the central banks of the affected countries raised interest rates to control the crisis. The increase in interest rates in some countries reached the "ethal level" for the business entities. In Indonesia, for example, interest rates at the time were above $40 \%$ pa. No business entity can survive with that "lethal interest". In a simulation made by Claessens et al. (1999) it was mentioned that the combination of the fall in exchange rates and rising interest rates caused $31 \%$ of the 400 large companies, that were 
sampled in Indonesia, Malaysia, Korea, the Philippines and Thailand, to become insolvent. Governments have to execute a "deadly interest rates" to save the exchange rate so that further fall does not occur. In most conditions, the interest rate is effective to influence the exchange rate monetary as desired.

In the organic system, the exchange rate uses the auto-balancing system so that it is not affected by speculative actions and other impurity factors, including government policies themselves. Even the money exchange transactions themselves do not affect the "price". The exchange rate in the organic model fully follows the (fundamentals) price index and true external balance. Therefore, organic currency does not require interest rates to control exchange rates. Likewise with the host country, the national central bank also does not need to adjust the interest rates of its national currency to control its exchange rate with organic currency. The exchange rate is always in true equilibrium.

Under such conditions, the OGC does not require interest rates at the central bank or government level. As for commercial banks, the policy is subject to each bank. In the absence of interest rates at the central bank level, and the absence of depreciation, commercial banks have greater freedom to determine the level of yield or profit-sharing. Commercial banks that operate according to Shari $a h$ principles also have greater freedom to determine the profitsharing system. There is no minimum risk-free rate; risk-free rate $=0$.

The condition, where the international currency is zero interest rate at the central bank level and is zero risk rate, is something new in global monetary affairs. Apart from our belief that it will make international monetary more efficient and more neutral, it is still the subject of further research on how its impact on international bank's intermediation functions.

\subsection{Zero volatility}

As mentioned above, the organic model uses its own exchange rate model called autobalancing. The auto-balancing is the exchange rate that uses the price index and neutral external balance as a parameter. The exchange rate between the OGC and the national currency is set at a parameter that "the national price index equals the global price index" and "external balance is neutral". There are three implications:

First, auto-balancing will create a global trade balance more than ever. The global imbalance that has been persistent so far can be eliminated. No country has a large surplus or a large deficit. All of their external balances are in equilibrium.

Second, the auto-balancing exchange rate follows the actual economic fundamentals in the true equilibrium of external balance. There is no gap or variance between monetary and real economy. In the absence of a gap, fluctuations are also gone. The exchange rate depicts the real value of the national currency and international (organic). Thus, the real-value changes of the national currency, such as inflation, will be fully and automatically adjusted by the exchange rate, in real-time.

Random walk to "certain direction"

The relationship between inflation or the price index with the exchange rate has long been a concern of economists because it is the basis of one price theory which is the building block of many other theories in an open economic model. However, although the theory is "theoretically per se" elegant, this is not the case with the proof. No one can prove the theory of one price holding globally and precisely as predicted. The relationship between the price index and the exchange rate remains a very long "puzzle".

As far as we know, all tests conducted by economists did not find a strong relationship between the price index and the exchange rate in the short term. Therefore they call exchange rate movements as "random walks" (Dornbusch, 1976); (Miller, 1984); (Daniel, 1986); (Engel and West, Exchange Rates and Fundamental, 2005); (Kulkarni and Nandakumar, 2011). However, in a longer or very long period, the relationship becomes 
IES

28,1

\section{6}

stronger (Abuaf and Jorion, 1990); (Cheung and S.Lai, 1993); (Enders and Hum, 1994); (Papell and Theodoridis, 1998) and (Sarno and Valente, 2006).

In common, various tests of the consistency between the exchange rate and the price index by many parties show the following results:

(1) The "random walk" of the floating exchange rate against the price index occurs in the short term,

(2) while in the long term, most test results indicate variants are lower. When the test method is strengthened and the period is extended, the relationship strengthens. And when the period is very long, which is a century, as in the Sarno and Valente (2006) test, the relationship is very strong.

This means, the exchange rate does not actually run randomly without direction but randomly goes in a certain direction. And that particular direction is the price index. In other words, the exchange rate, randomly and with some degree of variance, goes in the direction of the price index.

The current floating exchange rate is following the equilibrium of money markets, while the money markets are influenced by many factors that are not part of the fundamentals, such as speculative transactions, government intervention, imperfect information and so on. Rogoff (1996, p. 653) and Engel and Rogers (2001, p. 1) mentioned factors that cause a variance are transportation costs, barriers (tariff and non-tariff), non-tradable cost components, consumer fanaticism and rigid pricing systems. These factors cause the deviation between the exchange rate and the fundamental.

In the organic model, with the auto-balancing pegging the exchange rate directly on the price index and neutral external balance, the various volatile factors above are completely removed. Those factors no longer affect the exchange rate. Even the currency transaction itself does not affect the exchange rate. Whatever the demand or supply of OGC, the exchange rates with the local currency is not affected. The exchange rates always follow economic fundamentals. The volatility and variance are gone.

\subsection{Zero spreads}

Spread is the cost of currency exchange. The greater the spread the greater the cost of exchanging money. And conversely, the smaller the spread the smaller the cost. Dominant currencies usually have smaller spreads. This is because the currency is liquid or it has a larger economy of scale and thus lower exchange costs.

Besides, the spread is also related to volatility. Experts have been researching the relationship between spreads and volatility for a long time. Generally, they conclude the same thing, namely, the strong relationship between volatility and spreads. Among those researchers were Black (1991); Lyons (1993); Bollerslev and Melvin (1994); Wei (1994); Melvin and Tan (1996) and Ding (1999). Generally, their conclusions are the same, that is, the greater the volatility, the greater the spreads. In other words, the relationship is strong.

Why do spreads always exist in currency exchanges? Spreads come from two things:

First, profit margin.

The profit margin makes money-exchange services feasible on a business basis. Without spreads, money exchange services are not feasible in business so there will be no money exchange services, while the public requires money exchange markets for efficient exchange.

Second, risk of volatility.

The money exchange service provider is a passive party. They cannot decide when to sell or buy money. They only accept the exchanges made by economic agents who need money changers. So they are directly exposed to exchange rate volatility. Therefore they need an additional margin, above the profit margin, to cover the risk. 
As explained above, first, OGC is all digital and only circulates in the backbone network run by the central bank of each member country at the cost of them. As such, no additional fees are required for currency exchange services. So, the first point, the profit margin is not needed. The money exchange services do not need a profit margin. Second, as explained above, the auto-balancing can eliminate volatility. Thus, the second point, to cover the risk of volatility, becomes unnecessary. Thus, OGC does not require additional spread to provide profit margin or to cover the risks. In the organic model, spreads are not required in exchanging money.

In the organic model, money exchange services do not require a third party because they can be directly carried out on the backbone network operated by the central bank. In an advanced system in the future, exchange services by third parties still can be done without margins with the operating system as in the current social media where service providers only utilize advertising services and various other services to run their business. With this operational model, money exchange services by third parties are still possible with zero spread. New opportunities remain widely open.

Interchangeable and interconvertible

Organic currency is fully interchangeable or interconvertible. National currencies and international (organic) currency can be converted to each other without affecting exchange rates and without the need for spreads. Thus, the OGC and national currency cannot and do not need to be traded. Organic cryptocurrency is naturally non-tradable. Speculation will not exist.

The condition where exchange rates between international currency and national currencies are zero volatile and zero spreads is something new in global monetary affairs. Apart from our belief that it will make international monetary more stable, it is still the subject of further research on how it impacts on the money market, global trade and investment and global stability.

\section{The road to Sharíah principle}

The organic model aims to eliminate instabilities, inefficiencies, incoherence and imbalances in the current international monetary model. In doing so, the organic model follows basic theories in the open economy. Assessed from the direction, the organic model is on its way to achieve the Maquasid Sharíah.

First, the organic model makes global monetary more symmetrical: the global currency that is managed jointly by all countries in the world and is organically connected with the national currencies of all countries in the world, or at least member countries. Therefore, the OGC currency is more symmetrical and more democratic than the current model.

Our current international currencies are not the real international currency but the currencies of certain countries or regions that are adopted and used as international payment instruments. Thus, they give rise to global monetary asymmetry. Some countries or regions can print money from a piece of paper at almost no cost, while others must buy it with gold or real goods. Global monetary asymmetry creates widespread and permanent imbalances. The asymmetry of global monetary is the largest economic asymmetry in the world that causes permanent global imbalances, inequality and injustice. Many poor countries have to buy papers from the richest countries on earth with gold and any real goods that they badly need.

With the system which is controlled by all countries in the world or at least member countries democratically, the global monetary system will be more open and symmetrical. Countries in the world will have the same rights and equal opportunities to manage and create a common international currency. Thus, global imbalances can be eliminated, and global inequality can be reduced significantly. We believe that eliminating imbalances, inequality and injustice is part of the Maqāșid Sharíah. 
IES

28,1

Second, the OGC can be controlled directly so that it does not require the interest rate at the central bank or government level. We believe that in the absence of the interest rate at the central bank level, eliminating the interest rate on a fixed-rate basis at the lower level will be more likely than the current model. Without the interest rate, the cost of monetary control becomes more efficient.

In this model, interest rates can be eliminated only at the central bank level. For commercial banks, it is the subject of each bank. In the absence of the interest rate at the central bank level, and accompanied by zero depreciation, commercial banks have greater flexibility to reduce the costs of money "rent". Shariah banks and other Shariah-based financial institutions will have greater flexibility, more spaces, to create a revenue-or-profitsharing model that is closer to Shari ah principles. Various researches and breakthroughs in the future might be able to open the way on how to utilize money of zero-interest and zerodepreciation to increase growth and at the same time be closer to Maqūsid Sharíah.

Third, with the loss of volatility and spreads, the organic model removes currency speculation from the very basics: the opportunity. Trillions of US dollars of capital that have been circulating on the money market and only become "pseudo-and-volatile transactions" can be transferred and utilized for more useful real investments and consumptions that give real value addition to society. This model also eliminates the risk of fluctuations that each year cost the global economy hundreds of billions USD (Bonpasse, 2006, p. 161). By removing money trading opportunities, the organic model calls money back to its main function as a transaction tool, not as a commodity. The organic model can flow trillions of US dollars of capital which has so far only polluted global transactions back to the real sector so that it becomes more beneficial for humanity. This is a very deep achievement and a fundamental of the Maqāsid Sharíah.

\section{Conclusion}

We believe that the global economic and monetary system is always evolving towards better. There is no fixed and complete system. Evolution will continue throughout history into a more effective, more efficient, fairer and more stable system. We see that the organic model is part of the evolutionary process towards this good.

Likewise with Shariah economics. The principle in Shariah is fixed. It has been established in the Quran. But, creating a large monetary-economic system, which involves the interests of hundreds of millions and even billions of people, approaching the fixed principles of Shariah, we also believe, it is a process that will continue to evolve. We will never reach the final touch. But we do make it closer.

One of the main weaknesses of the current call for international monetary reform in various parts of the world, including those initiated by the IMF, is over-reliance on "agreements of countries and regions that control global currencies (the United States and the European Union) and the countries that control largest surplus in the world (China and Japan)". International monetary reform proposed today can only be carried out if all of those countries sit at one table and make a high-level agreement. And we all know reaching such a high level of agreement is impossible. Global monetary reform will never come from the top.

The organic model uses a completely different path. The organic model does not require the cooperation of all countries and has no dependency on the major player countries. The organic model only depends on the countries concerned. Then the concerning countries can start the initiative, establish the system and open it to all countries in the world. Then the reform will proceed naturally, gradually and give birth to disruption in global monetary system. The reform will proceed easily and naturally because it does not require economic integration. 
The journey to the ideal model and towards the Maqāsid Sharíah is a long journey, maybe even forever. What we can achieve in the organic model is part of the journey towards the ideal model and the Maquassid Shariah. As a new model, the OGM will continue to develop to achieve the optimum model, to achieve the stability and efficiency of monetary functions based on basic theories in an open economy, and at the same time increase its suitability for Maqāsid Sharíah. We are widely open to any input and cooperation from various parties, in all respects, to achieve the ideal model that becomes a legacy for mankind in the future, as rahmatan lil-alamin. Wallahu a'lam.

Organic global monetary

\section{References}

Abuaf, N. and Jorion, P. (1990), "Purchasing power parity in the long run", The Journal of Finance, Vol. 45 No. 1, pp. 157-174, doi: 10.1111/j.1540-6261.1990.tb05085.x.

Afshar, T.A. (2013), "Compare and contrast sukuk (Islamic bonds) with conventional bonds, are they compatible?", The Journal of Global Business Management, Vol. 9 No. 1, pp. 44-52, available at: http://www.jgbm.org.

Ajouz, M., Abdullah, A. and Kassim, S. (2019), "Developing a Sharīah-compliant precious metal backed cryptocurrency", Journal of King Abdulaziz University: Islamic Economics, Vol. 33 No. 1, pp. 3-20, doi: 10.4197/Islec.33-1.1.

Aste, T., Tasca, P. and Matteo, T.D. (2017), "Blockchain technologies: the foreseeable impact on society and industry", IEEE Computer, Vol. 50 No. 9, pp. 18-28, doi: 10.1109/MC.2017.3571064.

Ayub, M. (2007), Understanding Islamic Finance, John Willey \& Sons, West Sussex, available at: www. wiley.com.

BIS (2019), Triennial Central Bank Survey: Global Foreign Exchange Market Turnover in 2019, Monetary and Economic Department BIS, Basel, available at: https://www.bis.org.

Black, S.W. (1991), "Transactions costs and vehicle currencies", Journal of International Money and Finance, Vol. 10 No. 4, pp. 512-526. doi: 10.1016/0261-5606(91)90003-3.

Bollerslev, T. and Melvin, M. (1994), "Bid-ask spreads and volatility in the foreign exchange market; an empirical analysis", Journal of International Economics, Vol. 36, pp. 355-372, doi: 10.1016/ 0022-1996(94)90008-6.

Bonpasse, M. (2006), The Single Global Currency; Common Cents for the World Newcastle: Single Global Currency Association, \#15 of the 2006 edition ed., available at: www.singleglobalcurrency.org.

Brown, B. (2016), "The global $2 \%$ inflation standard - how will it end?", Atlantic Economic Journal, Vol. 44 No. 2, pp. 183-196, doi: 10.1007/s11293-016-9495-5.

Carneiro, F., Divino, J.A. and Rocha, C.H. (2002), "Revisiting the Fisher hypothesis for the cases of Argentina, Brazil and Mexico", Applied Economics Letters, Vol. 9 No. 2, pp. 95-98, doi: 10.2139/ SSRN.289824.

Cheung, Y.W. and Lai, S.K. (1993), "Long-run purchasing power parity during the recent float", Journal of International Economics, Vol. 34 Nos 1-2, pp. 181-192, doi: 10.1016/0022-1996(93) 90073-7.

Chohan, U.W. (2017), Cryptoanarchism and Cryptocurrencies, University of New South Wales, Discussion Paper, Sydney, doi: 10.2139/ssrn.3079241.

Choudhury, M.A. (2018), "Comparative Islamic perspectives in money, monetary policy, and social wellbeing", Journal of Economic Cooperation and Development, Vol. 39 No. 1, pp. 143-162 available at: https://www.sesric.org.

Claessens, S., Djankov, S. and Ferri, G. (1999), Corporate Distress in East Asia: The Effect of Currency and Interest Rate Shocks, Public Policy for Privat Sector, available at: https://siteresources. worldbank.org.

Clark, J. (2020), A Guide to Gold-Backed Cryptocurrency, available at: https://www.goldscape.net. 
IES

28,1

Cooper, R.N. (2006), "Proposal for a common currency among rich democracies. bank of Greece", Working Paper, Bank of Greece, Athens, pp. 5-15, available at: www.bankofgreece.gr.

Daniel, B.C. (1986), "Sticky prices and purchasing power parity deviations: empirical implications", Economics Letters, Vol. 20 No. 2, pp. 187-190, doi: 10.1016/0165-1765(86)90170-9.

Ding, D.K. (1999), "The determinants of bid-ask spreads in the foreign exchange futures market: a microstructure analysis", Journal of Futures Markets, Vol. 19 No. 3, pp. 307-324, doi: 10.1002/fut. 3990030306.

Dornbusch, R. (1976), "Expectations and exchange rate dynamics", Journal of Political Economy, Vol. 84 No. 6, pp. 1161-1176, available at: https://www.jstor.org/stable/1831272.

Eichengreen, B., Rose, A.K. and Wyplosz, C. (1994), "Speculative attacks on pegged exchange rates: an empirical exploration with special reference to the European monetary system", NBER Working Papers, NBER, Cambridge, doi: 10.3386/W4898.

Enders, W. and Hum, S. (1994), "Theory and tests of generalized purchasing-power parity: common trends and real exchange rates in the pacific rim", Reviews of International Economics, Vol. 2 No. 2, pp. 179-190, doi: 10.1111/j.1467-9396.1994.tb00039.x.

Engel, C. and Rogers, J.H. (2001), "Deviations from purchasing power parity: causes and welfare costs", Journal of International Economics, Vol. 55 No. 1, pp. 29-57, doi: 10.1016/S0022-1996(01)00094-0.

Engel, C. and West, K.D. (2005), "Exchange rates and fundamental", Journal of Political Economy, Vol. 113 No. 3, pp. 485-517, available at: https://www.ssc.wisc.edu.

Fisher, I. (1911), The Purchasing Power of Money, its Determination and Relation to Credit, Interest. Indianapolis, Liberty Fund, available at: http:/oll.libertyfund.org.

Fisher, I. (1930), The Theory of Interest, The McMillan Company, New York, NY, available at: http:// files.libertyfund.org.

Greenwald, B.C. and Stiglitz, J.E. (2009), “A modest proposal for international monetary reform”, Initiative for Policy Dialogue Working Paper Series. doi: 10.7916/D8V98H8Q.

Hayward, R. (2018), "Foreign exchange speculation: an event Study", International Journal of Financial Studies, Vol. 6 No. 1, pp. 1-13, doi: 10.3390/IJFS6010022.

Hsieh, Y.Y., Vergne, J.P., Anderson, P. and Lakhani, K. (2018), "Bitcoin and the rise of decentralized autonomous organizations”, Journal of Organization Design, Vol. 7 No. 1, pp. 1-16, doi: 10.1186/ S41469-018-0038-1.

IMF (2010), "Reserve accumulation and international monetary stability", IMF Policy Papers, IMF, Washington DC, available at: https://www.imf.org.

IMF (2011), Enhancing International Monetary Stability - A Role for the SDR? IMF Policy Papers, IMF, Washington DC, available at: https://www.imf.org.

Inflationtool (2020), Value of 1999 Euro Today Inflationtool, available at: https://www.inflationtool.com.

Katz, J. and Lindell, Y. (2015), Introduction to Modern Cryptography, 2nd ed., Chapman \& Hall/CRC, Boca Raton, available at: http://www.crcpress.com.

Keynes, J.M. (1969)The Keynes plan; proposals for an international clearing union, IMF, the International Monetary Fund 1945-1965, IMF, Washington DC, Vol. III, pp. 19-36, available at: https://www.elibrary.imf.org.

Krugman, P.R. and Obstfeld, M. (2003), International Economics: Theory and Policy, 6th ed., Pearson Education, Boston.

Kruger, M. (1996), Speculation, Hedging and Intermediation in the Foreign Exchange Market, Documentos de Trabajo del Banco de EspañaBanco de España, Madrid, available at: https:// www.bde.es.

Kulkarni, K.G. and Nandakumar, P. (2011), "Short-run deviations from purchasing power parity (PPP): a case of expectational changes", Journal of Applied Business Research, Vol. 8 No. 2, pp. 122-126, doi: 10.19030/jabr.v8i2.6174. 
Lietaer, B. (2017), "A possibly Sharíah-compatible global currency to stabilize the monetary system”, Islamic Econ, Vol. 30 No. 2, pp. 47-58, doi: 10.4197/Islec.30-2.4.

Litterman, R.B. (1982), Optimal Control of the Money Supply, NBER Working PaperNBER, Cambridge, doi: 10.3386/W0912.

Lyons, R.K. (1993), "Tests of microstructural hypotheses in the foreign exchange market", NBER, Cambridge NBER Working Paper No. w4471, available at: https://www.nber.org.

Meltzer, A.H. (2004), "Origins of the great inflation”, Canadian Parliamentary Review, Vol. 87 No. 2, pp. 145-176, doi: 10.20955/R.87.145-176.

Melvin, M. and Tan, K.-H. (1996), "Foreign exchange market bid—ask spreads and the market price of social unrest", Oxford Economic Papers, Vol. 48 No. 2, pp.329-341, doi: 10.1093/OXFORDJOURNALS. OEP.A028571.

Mignon, V. and Lardic, S. (2003), "Fractional cointegration between nominal interest rates and inflation: a Re-examination of the Fisher relationship in the G7 countries", Economics Bulletin, Vol. 3 No. 14, pp. 1-10.

Miller, S. (1984), "Purchasing power parity and relative price variability: evidence from the 1970s", European Economic Review, Vol. 26 No. 3, pp. 353-367, doi: 10.1016/0014-2921(84)90096-5.

Moore, B.J. (2004), "A global currency for a global economy", Journal of Post Keynesian Economics, Vol. 26 No. 4, pp. 631-653, doi: 10.1080/01603477.2004.11051415.

Mundell, R.A. (1961), "A theory of optimum currency areas”, The American Economic Review, Vol. 51 No. 4, pp. 657-665.

Mundell, R.A. (2003), The International Monetary System and the Case for a World Currency. Distinguished Lectures Series N. 12, WSPiZ and TIGER, Warsawa, available at: https:/tiger. edu.pl.

Muse, B.O. and Alimi, R.S. (2012), "Testing an augmented Fisher hypothesis for a small open economy: the case of Nigeria”, Akungba Journal of Management, Vol. 4 No. 1, pp. 33-44, available at: https://mpra.ub.uni-muenchen.de.

Obstfeld, M. and Rogoff, K. (2010), Global Imbalances and the Financial Crisis: Products of Common Causes. CEPR Discussion, CEPR, Washington, DC, Paper No. DP7606, pp. 1-72, available at: https://EconPapers.repec.org.

Papell, D.H. and Theodoridis, H. (1998), "Increasing evidence of purchasing power parity over the current float”, Journal of International Money and Finance, Vol. 17 No. 1, pp. 41-50, doi: 10.1016/ S0261-5606(97)00050-8.

Rahman, A.R. (2007), "Islamic banking and finance: between ideals and realities", IIUM Journal of Economics and Management, Vol. 15 No. 2, pp. 123-141, available at: https://journals.iium. edu.my.

Rahman, A.A. (2020), Currency Democracy: The Theory of Organic Global Monetary, 2nd ed., GCI, Jakarta, available at: https://books.google.com.

Reisen, H. (1998), "Domestic causes of currency crises: policy lessons for crisis avoidance", IDS Bulletin, Vol. 30 No. 1, pp. 120-133, doi: 10.1111/J.1759-5436.1999.MP30001011.X.

Rodrik, D. (2008), "The real exchange rate and economic growth", Brookings Papers on Economic Activity, Fall 2008, Vol. 2, pp. 365-439, doi: 10.1353/ECA.0.0020.

Rogoff, K. (1996), “The purchasing power parity puzzle”, Journal of Economic Literature, Vol. 34 No. 2, pp. 647-668, available at: http://ohu.people.ysu.edu.

Sarno, L. and Valente, G. (2006), "Deviations from purchasing power parity under different exchange rate regimes: do they revert and, if so, how?", Journal of Banking and Finance, Elsevier, Vol. 33 No. 11, pp. 3147-3169, doi: 10.1016/j.jbankfin.2005.12.007.

Siddiqi, M.N. (2006), "Islamic banking and finance in theory and practice: a Survey of state of the art", Islamic Economic Studies, Vol. 13 No. 2, pp. 2-48, available at: http://www.irti.org. 
IES

28,1

82
ST Louis, F. (2020), "Consumer price index for all Urban consumers: purchasing power of the consumer dollar in U.S. City average", available at: https://fred.stlouisfed.org.

Tobin, J. (1978), “A proposal for international monetary reform”, Eastern Economic Journal, Vol. 4 Nos 3-4, pp. 153-159, available at: https://web.holycross.edu.

Wei, S.J. (1994), "Anticipations of foreign exchange volatility and bid-ask spreads", Working Paper No. 4737, available at: http://www.nber.org.

Westerlund, J. (2008), "Panel cointegration tests of the Fisher effect", Journal of Applied Econometrics, Vol. 23 No. 2, pp. 193-233, doi: 10.1002/JAE.967.

Wilson, R. (2008), "Innovation in the structuring of Islamic sukuk securities", Humanomics, Vol. 24 No. 3, pp. 170-181, doi: 10.1108/08288660810899340.

Zhang, Z. (2001), Speculative Attack in the Asian Crisis, IMF, Washington DC IMF working paper 189, available at: https://www.imf.org.

\section{Further reading}

Appelt, K. (2015), "Keynes' theory of the interest rate: a critical approach", Theory, Methodology, Practice, Vol. 12 No. 1, pp. 3-8, doi: 10.18096/TMP.2016.01.01.

Chodorow-Reich, G. (2014), "The employment effects of credit market disruptions: firm-level evidence from the 2008-2009 financial crisis", Quarterly Journal of Economics, Vol. 129 No. 1, pp. 1-59, doi: 10.1093/QJE/QJT031.

Karim, Z.A. (2012), "Monetary policy effects on investment Spending: a firm-level Study of Malaysia", Studies in Economics and Finance, Vol. 29 No. 4, pp. 268-286, doi: 10.1108/10867371211266919.

Shalishali, M.K. and Ho, J.C. (2002), "Inflation, interest rate, and exchange rate: what is the relationship?", Journal of Economics and Economic Education, Vol. 3 No. 1, pp. 107-117.

Tsabita, R., Triyuwono, I. and Achsin, M. (2016), "Mengungkap ketidakadilan dalam praktik pembiayaan mudharabah: Studi fenomenologi”, El Muhasaba: Jurnal Akuntansi, Vol. 6 No. 1, pp. 1-16, doi: 10.18860/EM.V6I1.3868.

United Nations (2020), World Economic Situation and Prospects 2020, United Nation, New York, NY, available at: https://books.google.co.id.

\section{Corresponding author}

Abdurrahman Arum Rahman can be contacted at: globalcurrencyinitiative@gmail.com

For instructions on how to order reprints of this article, please visit our website:

www.emeraldgrouppublishing.com/licensing/reprints.htm

Or contact us for further details: permissions@emeraldinsight.com 